\title{
Influence of rare earth elements (REEs) on structure and optical properties of lithium zirconium phosphate (LZP)
}

Received 00th January 20xx, Accepted 00th January 20xx

DOI: $10.1039 / \times 0 \times x 00000 x$

\author{
Gorodylova Nataliia, ${ }^{* a}$ Kosinová Veronika ${ }^{a}$ and Šulcová Petra ${ }^{a}$
}

The concept of realisation of different substitution models in REE-LZP crystall structure where REEs occupy either Li+ ${ }^{+}$or $\mathrm{Zr}^{4+}$ crystallographic positions corresponding to triclinic $\mathrm{Li}_{1-3 x} \mathrm{REE}_{\mathrm{x}} \mathrm{Zr}_{2}\left(\mathrm{PO}_{4}\right)_{3}$ or NASICON-like ion conductive rhombohedral $\mathrm{Li}_{1+x} \mathrm{Zr}_{2-\mathrm{x}} \mathrm{REE} \mathrm{E}_{\mathrm{x}}\left(\mathrm{PO}_{4}\right)_{3}$ phases was verified. Different synthesis approaches (a polymerizable-complex Pechini method and solid state reaction) were tested to obtain polycristalline samples with $R E E=L a$ and $x=0.1$. Reaction mechanism in the mixtures was explained using thermal analysis and XRD. On basis of the obtained results, the most suitable synthesis method with regards to the phase composition (PM) was applied to obtain the whole series of REE-LZPs in order to verify their crystall structure and characterise their optical properties for pigment application. It is shown that realisation of the different substitution models in LZP polycristalline samples can be distinguished by high resolution X-ray powder analysis that confirmed co-existence of the both types of solid solutions. However, REE-LZP phases have limited thermal stability and in the studied conditions can be obtained only in mixture with not-substituted $\beta$-LZP. Moreover, Li excess, typically used to achieve the formation of pure-phase LZP product, in the studied case induced REE replacement off the LZP structure producing (REE) $\mathrm{PO}_{4}$ phase. It is shown that some REEs ( $\mathrm{Nd}, \mathrm{Tb}$, Ho and $\mathrm{Pr}$ ) induce in LZP ceramics attractive colouration varied from purple to yellow and green shades, which is pre-determined by crystal structure of prevailing REE-LZP phase and in some cases is sensitive to ambient light due to luminescent properties of REEs.

\section{Introduction}

Lithium zirconium phosphate $\left(\operatorname{LiZr}_{2}\left(\mathrm{PO}_{4}\right)_{3}, \mathrm{LZP}\right)$ represents an important object of investigation characterised with valuable properties for high-tech applications ${ }^{1-3}$. Among others, LZP-based materials of NASICON (NAtrium Super lonic CONductor) type have been intensively studied as one of the most promising solid electrolytes for application in rechargeable ionic batteries with improved safety and advanced parameters ${ }^{1,4-8}$. In particular, the rhombohedral modification of LZP has been recently reported to provide high bulk Li-ion conductivity, high electrochemical stability and a small interfacial resistance for $\mathrm{Li}^{+}$transfer ${ }^{6}$. The rhombohedral LZP with NASICON-like structure is a high temperature modification of $\mathrm{LiZr}_{2}\left(\mathrm{PO}_{4}\right)_{3}$ which exhibits a complex structural polymorphism. A common approach to achieve stabilization of high-temperature rhombohedral LZP phase with high ionic conductivity at room temperatures (RT) is its substitution by REEs ${ }^{9-13}$. However, the crystal structure of the REE-substituted compounds on basis of LZP may vary. According to the literature analysis, two substitution models where REEs may occupy either $\mathrm{Li}^{+}$or $\mathrm{Zr}^{4+}$ crystallographic positions could be realised leading to different crystal symmetry distortion resulting in varied properties.

In particular, from crystallographic point of view, REEs are supposed to occupy charge compensation cationic sites in the LZP crystal matrix. These positions are partially occupied by $\mathrm{Li}^{+}$ions too and, in view of large ionic radii of REEs, are the most size-suitable cationic sites. This type of substitution has been realised in continuous solid solutions of general formula $\mathrm{Li}_{1-3 x} \mathrm{La}_{x} \mathrm{Zr}_{2}\left(\mathrm{PO}_{4}\right)_{3}(0 \leq x \leq 1 / 3)$ reported a. University of Pardubice, Faculty of Chemical Technology, Department of Inorganic
Technology, Studentská 95, 532 10, Pardubice, Czech Republic.

*Corresponding author: tel. +420 466037 182; e-mail nataliia.gorodylova@upce.cz for $\operatorname{LiZr}_{2}\left(\mathrm{PO}_{4}\right)_{3}-\mathrm{La}_{1 / 3} \mathrm{Zr}_{2}\left(\mathrm{PO}_{4}\right)_{3}$ system ${ }^{14}$. The crystal symmetry of the solid solutions depends on the substitution degree $x$ and varies at RT from triclinic $(x \leq 1 / 6)$ via rhombohedral $(1 / 6<x<1 / 3)$ to trigonal $(x=$ $1 / 3)$. The formation of these solid solutions can be described by the substitution model ' $\mathrm{Li} \mathrm{La}^{\prime}: \mathrm{Li}^{+} \rightarrow 1 / 3 \mathrm{La}^{3+}+2 / 3 \square$, where the large $\mathrm{La}^{3+}$ ions occupy the ion compensation sites shared with $\mathrm{Li}^{+}$leading to an increase of the vacancies number correlated to an increase of the $\mathrm{La}^{3+}$ content (Table 1). The end-member of the solid solutions, $\mathrm{La}_{1 / 3} \mathrm{Zr}_{2}\left(\mathrm{PO}_{4}\right)_{3}$, adopts at RT trigonal structure where La-O interatomic distances vary from 2.47 to $2.9 \AA$ and those of $\mathrm{Zr}-\mathrm{O}$ from 1.95 to $2.2 \AA^{15}$. The comparison suggests that alternative cationic positions of $Z r$ should be too small to host the large REEs in the LZP structure.

However, realisation of the substitution model corresponding to general formula $\mathrm{Li}_{1+\mathrm{x}} \mathrm{Zr}_{2-\mathrm{x}} \mathrm{REE}_{\mathrm{x}}\left(\mathrm{PO}_{4}\right)_{3}(\mathrm{REE}=\mathrm{La}, \mathrm{Y}, \mathrm{x} \leq 1)$ where $\mathrm{REE}$ substitutes $\mathrm{Zr}$ was also reported ${ }^{9,10,13,16,17}$. Crystallographycally, it results from stabilization of the rhombohedral LZP phase of NASICON type with high ionic conductivity. However, the formation of pure rhombohedral $\mathrm{Li}_{1+x} \mathrm{Zr}_{2-\mathrm{x}} \mathrm{REE}_{\mathrm{x}}\left(\mathrm{PO}_{4}\right)_{3}$ phases was reported to take place only in a very limited substitution range (in most studies it is limited to $x \leq 0.4)^{9,10,16-18}$. Realisation of this type of solid solutions takes place in $\operatorname{LiZr}_{2}\left(\mathrm{PO}_{4}\right)_{3}$ - $\mathrm{Li}(\mathrm{REE})_{2}\left(\mathrm{PO}_{4}\right)_{3}$ system where REE ions share crystallographic position with $\mathrm{Zr}^{4+}$ described by the substitution model ' $\mathrm{Zr} / \mathrm{La}^{\prime}: \mathrm{Zr}^{4+} \rightarrow \mathrm{La}^{3+}+\mathrm{Li}^{+}$(Table 1). According to the powder XRD analysis and Rietveld refinement ${ }^{9,10,16,17}$, the substitution of $\mathrm{Zr}$ by REE do stabilises highly conducting rhombohedral LZP phase at RT, however no X-Ray or neutron diffraction studies have been performed for these type of compounds to confirm their structure. From crystallographic point of view, due to the large difference between $\mathrm{Zr}$ ionic radii $(0.72 \AA)$ and those of the REEs $(>0.9 \AA)^{19}$, it is very unlikely that the framework zirconium positions of the rhombohedral LZPs where $\mathrm{Zr}-\mathrm{O}$ is only about $2.06 \AA^{20}$ host large cations such as La or Y. Moreover, REEs compositional analogue of 


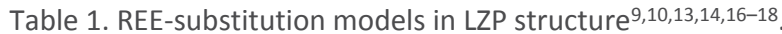

\begin{tabular}{|c|c|c|c|c|c|}
\hline \multicolumn{2}{|c|}{ Substitution model } & System & Formula & $x$ & Structure symmetry \\
\hline \multirow[t]{3}{*}{$\mathrm{Li} / \mathrm{REE}$} & \multirow[t]{3}{*}{$\mathrm{Li}^{+} \rightarrow 1 / 3 \mathrm{REE}^{3+}+2 / 3 \square$} & \multirow{3}{*}{$\mathrm{LiZr}_{2}\left(\mathrm{PO}_{4}\right)_{3}-\mathrm{La}_{1 / 3} \mathrm{Zr}_{2}\left(\mathrm{PO}_{4}\right)_{3}$} & \multirow{3}{*}{$\mathrm{Li}_{1-3 x} \mathrm{La}_{x} \mathrm{Zr}_{2}\left(\mathrm{PO}_{4}\right)_{3}$} & $x \leq 1 / 6$ & Triclinic \\
\hline & & & & $1 / 6<x<1 / 3$ & Rhombohedral \\
\hline & & & & $x=1 / 3$ & Trigonal \\
\hline Zr/REE & $\mathrm{Zr}^{4+} \rightarrow \mathrm{REE}^{3+}+\mathrm{Li}^{+}$ & $\mathrm{LiZr}_{2}\left(\mathrm{PO}_{4}\right)_{3}-\mathrm{Li}(\mathrm{REE})_{2}\left(\mathrm{PO}_{4}\right)_{3}$ & $\mathrm{Li}_{1+x} \mathrm{Zr}_{2-\mathrm{x}} \mathrm{REE}_{\mathrm{x}}\left(\mathrm{PO}_{4}\right)_{3}$ & $x \leq 1$ & Rhombohedral NASICON-like \\
\hline
\end{tabular}

$\mathrm{LiZr}_{2}\left(\mathrm{PO}_{4}\right)_{3}$ in such substitution model is $\mathrm{Li}(\mathrm{REE})_{2}\left(\mathrm{PO}_{4}\right)_{3}$, which adopts a totally unrelated structure type of monoclinic monazite, that excludes the possibility of the formation of the continuous solid solutions between $\mathrm{LiZr}_{2}\left(\mathrm{PO}_{4}\right)_{3}$ and $\mathrm{A}(\mathrm{REE})_{2}\left(\mathrm{PO}_{4}\right)_{3}{ }^{18}$. In this view, coexistence of two modifications of REE-substituted LZP ceramics in the low substitution range is an open scientific question that requires additional examination and proves.

Besides application in the field of ionic conductors, REE-LZP also found application as adsorbent ${ }^{17}$. Moreover, REE-substitution may also induce attractive colouration to white LZP ceramics, which in combination with its thermal stability makes it attractive candidate for application as high performance inorganic pigment. The primary demands to this class of pigments include outstanding optical and thermal properties as well as chemical stability at high temperatures and resistance to aggressive media such as melted glazes ${ }^{21}$. Previously, it has been already reported, that La-substituted LZPs exhibit good chemical and structural stability and are resistant to air water, Li metal, acidic and basic solutions ${ }^{10}$. However, there are no reports focused on detailed investigation on VIS reflectance and colour analysis of REE-LZPs and their potential for pigment application.

The objective of presented study was to verify the concept of the formation of the solid solutions according to two different substitution models $\left(\mathrm{Li}_{1-3 \mathrm{x}} \mathrm{REE} \mathrm{Zr}_{\mathrm{x}}\left(\mathrm{PO}_{4}\right)_{3}\right.$ and $\left.\mathrm{Li}_{1+\mathrm{x}} \mathrm{Zr}_{2-\mathrm{x}} \mathrm{REE}_{\mathrm{x}}\left(\mathrm{PO}_{4}\right)_{3}\right)$ and to examine optical absorption properties of the samples for pigment application.

\section{Experimental}

Synthesis of the La-modified LZP solid solutions with La content 0.1 corresponding to $\mathrm{Li}_{0.7} \mathrm{La}_{0.1} \mathrm{Zr}_{2}\left(\mathrm{PO}_{4}\right)_{3}$ (representing $\mathrm{Li}_{1-3 \mathrm{x}} \mathrm{La}_{\mathrm{x}} \mathrm{Zr}_{2}\left(\mathrm{PO}_{4}\right)_{3}$ substitution model) and $\mathrm{Li}_{1.1} \mathrm{Zr}_{1.9} \mathrm{La}_{0.1}\left(\mathrm{PO}_{4}\right)_{3}$ (representing $\mathrm{Li}_{1+\times} \mathrm{Zr}_{2-}$ ${ }_{x} \mathrm{La}_{x}\left(\mathrm{PO}_{4}\right)_{3}$ substitution model) was performed by a polymerizablecomplex method based on Pechini method (PM) and a solid state reaction (SSR).

For PM approach, stoichiometric amount of $\mathrm{LiNO}_{3}$ (P.A., Lachema, $\mathrm{CZ}$ ), $\mathrm{La}\left(\mathrm{NO}_{3}\right)_{3} \cdot 6 \mathrm{H}_{2} \mathrm{O}$ (P.A., Merck, DE), $\mathrm{ZrOCl}_{2} \cdot 8 \mathrm{H}_{2} \mathrm{O}$ (P.A., Merck, DE) were separately dissolved in deionized water, mixed with citric acid (CA, $\mathrm{C}_{6} \mathrm{H}_{8} \mathrm{O}_{7} \cdot \mathrm{H}_{2} \mathrm{O}$, P.A., Lach-Ner, $\mathrm{CZ}$ ) in $\mathrm{CA} /$ metal ions molar ratio 4 during $2 \mathrm{~h}$ under stirring at RT that allowed to homogenize and form metal chelates. Next, ethylene glycol (EG, $\mathrm{C}_{2} \mathrm{H}_{6} \mathrm{O}_{2}$, P.A., Lach-Ner, $\mathrm{CZ}$ ) in molar ratio $\mathrm{CA}: \mathrm{EG}=1: 4$ was added. Esterification between $\mathrm{CA}$ and EG was promoted by heating at $60{ }^{\circ} \mathrm{C}$ resulting in the formation of viscous gel. Stoichiometric amount of dissolved $\mathrm{NH}_{4} \mathrm{H}_{2} \mathrm{PO}_{4}$ (P.A., Lachema, CZ) was added in two different way: in one case it was added simultaneously with EG; in another case it was added $2 \mathrm{~h}$ after addition of EG. In both cases, addition of phosphate promoted formation of solid particles that substantially increased the viscosity of the mixture. The obtained white suspensions were kept under stirring and moderate heating for several hours and then dried at 150 ${ }^{\circ} \mathrm{C}$ during $24 \mathrm{~h}$ followed by treatment at $250{ }^{\circ} \mathrm{C}$ during $12 \mathrm{~h}$. In result, black solid precursor was obtained. Annealing of the precursor was performed in an electric furnace between 600 and $1400{ }^{\circ} \mathrm{C}$ during 2$48 \mathrm{~h}$ using a heating rate $1-2{ }^{\circ} \mathrm{C} / \mathrm{min}$.
In another synthesis approach, SSR, a stoichiometric mixture of $\mathrm{Li}_{2} \mathrm{CO}_{3}$ (P.A., Lachema, CZ), $\mathrm{La}_{2}\left(\mathrm{CO}_{3}\right)_{3} \cdot \mathrm{XH}_{2} \mathrm{O}$ (P.A., Aldrich, DE), $\mathrm{ZrOCl}_{2} \cdot 8 \mathrm{H}_{2} \mathrm{O}$ (P.A., Merck, DE) and $\left(\mathrm{NH}_{4}\right)_{2} \mathrm{HPO}_{4}$ (P.A., Lachema, CZ) was thoroughly ground in an agate mortar with a pestle, transferred into corundum crucibles and slowly heated to $600{ }^{\circ} \mathrm{C}$ in an electric furnace with heating rate $1-2{ }^{\circ} \mathrm{C} / \mathrm{min}$. After calcination at $600{ }^{\circ} \mathrm{C}$ during $30 \mathrm{~min}$, the samples were slowly cooled down to RT, reground in an automatic mortar grinder and pressed to form high-density pellets with $2-3 \mathrm{~mm}$ thick and $10 \mathrm{~mm}$ in diameter using a stainless press form and a laboratory press at 150-200 Bar. The pellets were calcined in an electric furnace at $600-1400{ }^{\circ} \mathrm{C}$ during $2-48 \mathrm{~h}$ using a heating rate $2{ }^{\circ} \mathrm{C} / \mathrm{min}$. After each calcination step, the samples were reground in automatic mortar grinder during 5-10 min and shaped again to form high-density pellets.

Thermal transformations of the initial chemical compounds, reaction mixtures and precursors were studied using thermal analysis, TA (DSC-TGA, Labsys Evo 1600, Setaram, FR). The measurements were performed in corundum crucibles in Ar flow, $50 \mathrm{ml} / \mathrm{min}$, in a temperature range of $25-1200^{\circ} \mathrm{C}$ with a heating rate of $10^{\circ} \mathrm{C} / \mathrm{min}$ ). After each calcination step, the ceramic samples were ground and the obtained fine powders were subjected to phase composition analysis performed by a benchtop diffractometer Miniflex 600 (Rigaku, JAP) using the following settings: CuK $\alpha$ radiation $\left(\mathrm{CuK}_{\beta} \mathrm{Ni}\right.$ filter), 1D detector $\mathrm{D} /$ teX Ultra, continuous scanning over 2 theta range from 10 to $80^{\circ}$ with scanning speed of $5-10^{\circ} 2$ theta/min, recorded step size $0.02^{\circ}$. Crystal phase identification was performed using PDXL2 Rigaku data analysis software and PDF-2 database. In this paper, the optimised XRD patterns are displayed on the artwork related to XRD analysis.

The colour properties of the samples were analysed by measurement of spectral reflectance in the visible region of light $(400-700 \mathrm{~nm})$ using a spectrophotometer (ColorQuest XE, HunterLab, USA). The measurement was performed for the powdered samples handpressed into quartz cuvettes. The measurement conditions were as follows: a standard illuminant $D_{65}$ (daylight), $10^{\circ}$ standard observer and measuring geometry $\mathrm{d} / 8^{\circ}$. Experimental colorimetric parameters were calculated from diffuse-reflectance spectra. The colour properties are discussed in terms of $\operatorname{CIE} L^{*} a^{*} b^{*}$ and $\mathrm{CIE} L{ }^{*} C^{*} h^{\circ}$ systems recommended by CIE (Comission Internationale de l'Eclairage ${ }^{22}$ ). For each sample, the colour parameters were measured trice and the average value was chosen as its result. Generally, for a given sample, the standard deviation of the measured colour parameters was $<0.10$ and the relative standard deviation was $\leq 1 \%$, indicating that the measurement error can be ignored.

\section{Results and discussion}

\section{TA and XRD study of the formation of La-substituted LZP}

A polymerizable-complex method based on Pechini method (PM) and a solid state reaction (SSR) were selected for the synthesis of the samples. Previously, PM approach has been reported to be suitable for realisation of the both substitution models ${ }^{10,14,16}$, while SSR has 
been used before only to obtain $\mathrm{Li}_{1+x} \mathrm{Zr}_{2-x} \mathrm{REE}_{\mathrm{x}}\left(\mathrm{PO}_{4}\right)_{3}$ series with $\mathrm{R}-3 \mathrm{c}$ NASICON-like LZP structure ${ }^{9,17}$. In our study, the substitution degree $x$ in both models was limited to 0.1 giving $\mathrm{Li}_{0.7} \mathrm{La}_{0.1} \mathrm{Zr}_{2}\left(\mathrm{PO}_{4}\right)_{3}$ and $\mathrm{Li}_{1.1} \mathrm{Zr}_{1.9} \mathrm{La}_{0.1}\left(\mathrm{PO}_{4}\right)_{3}$ compositions that lay within the previously reported range of existence of the solid solutions in the both substitution models. Interactions in the reaction mixtures leading to the formation of La-modified LZP solid solutions were studied by TA and XRD analysis. The results of TA in the temperature range of 25$600{ }^{\circ} \mathrm{C}$ are presented in Fig 1 . According to the results, thermal behaviour of the reaction mixtures differs considerably depending on the synthesis approach (SSR or PM).

TA of the raw mixtures of the initial reagents for SSR $\left(\mathrm{Li}_{2} \mathrm{CO}_{3}\right.$, $\mathrm{La}_{2}\left(\mathrm{CO}_{3}\right)_{3} \cdot \times \mathrm{H}_{2} \mathrm{O}, \mathrm{ZrOCl}_{2} \cdot 8 \mathrm{H}_{2} \mathrm{O}$ and $\left.\left(\mathrm{NH}_{4}\right)_{2} \mathrm{HPO}_{4}\right)$ has revealed complex transformations corresponding to multiple overlapping endothermic reactions. Each of the observed endothermic effects is accompanied by weight loss that is clearly seen from comparison of DSC and DTG curves of the samples. At the same time, thermal behaviour of the samples with different composition corresponding to different types of solid solutions $\left(\mathrm{Li}_{0.7} \mathrm{La}_{0.1} \mathrm{Zr}_{2}\left(\mathrm{PO}_{4}\right)_{3}\right.$ or $\left.\mathrm{Li}_{1.1} \mathrm{Zr}_{1.9} \mathrm{La}_{0.1}\left(\mathrm{PO}_{4}\right)_{3}\right)$ was very close to each other that can be explained by a minor difference in the chemical composition of the initial mixtures (Fig. 1, SSR). The main difference that is noticeable on TA curves is higher content of $\mathrm{ZrOCl} 2 \cdot 8 \mathrm{H}_{2} \mathrm{O}$ component in $\mathrm{Li}_{0.7} \mathrm{La}_{0.1} \mathrm{Zr}_{2}\left(\mathrm{PO}_{4}\right)_{3}$ sample. Because $\mathrm{ZrOCl} \cdot 8 \mathrm{H}_{2} \mathrm{O}$ is one of the main components that contributes to the observed TA transformations, the weight loss in this sample progresses more intensively and reaches higher values in comparison to $\mathrm{Li}_{1.1} \mathrm{Zr}_{1.9} \mathrm{La}_{0.1}\left(\mathrm{PO}_{4}\right)_{3}$ sample.

Upon heating, the first process that is detected on TA curves is dehydration. Accordingly, the first endothermic effect at $120^{\circ} \mathrm{C}$ and the associated weight loss can be attributed to dehydration of crystallohydrates present in the mixture $\left(\mathrm{ZrOCl}_{2} \cdot 8 \mathrm{H}_{2} \mathrm{O}\right.$ and $\left.\mathrm{La}_{2}\left(\mathrm{CO}_{3}\right)_{3} \cdot \mathrm{xH}_{2} \mathrm{O}\right)$. The calculated weight loss corresponding to this process should reach $25 \%$ of the total mixture weight. However the observed values are lower that can be explained with partia dehydration that happened during the sample storage in a desiccator

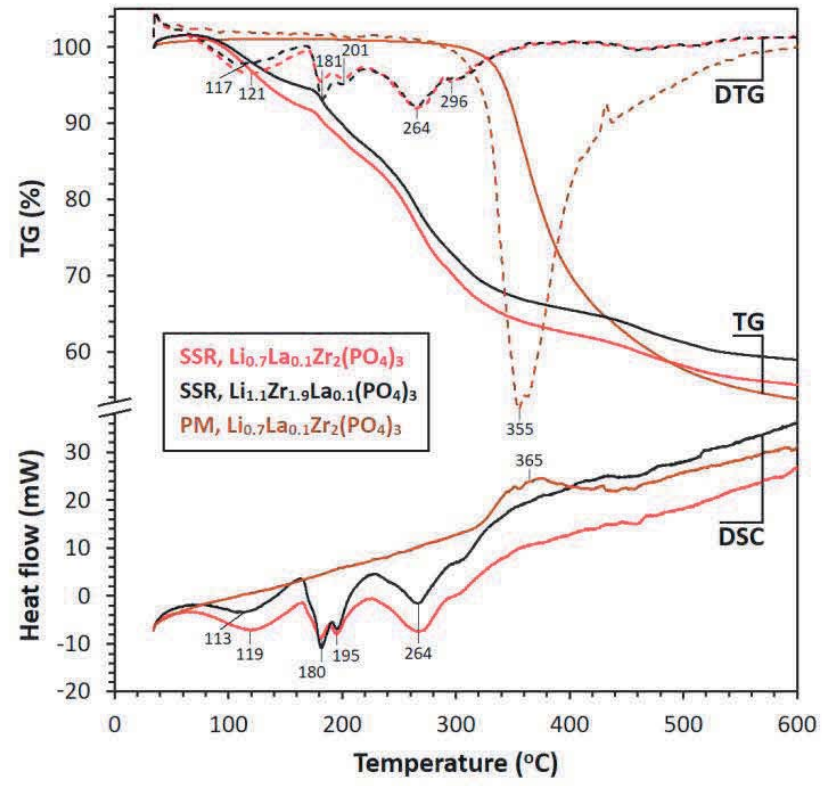

Fig. 1. Results of TA of the raw mixtures of the SSR initial reagents and PM precursor (pre-treated at $250^{\circ} \mathrm{C}, 12 \mathrm{~h}$ ). prior to TA analysis. It also contributed to decrease of the total weight loss of the mixtures by 10-12 \% from the calculated theoretical values (experimental weight loss is $43-46 \%$ against theoretical $56 \%$ ). The second endothermic effect that is clearly divided in 2 separate processes can be attributed to elimination of ammonia of $\left(\mathrm{NH}_{4}\right)_{2} \mathrm{HPO}_{4}$ and reaction with carbonates. XRD analysis has confirmed transformation of lanthanum carbonate into lanthanum phosphates at $200^{\circ} \mathrm{C}$. However, presence of not reacted lithium carbonate has been detected as well that indicates that lanthanum carbonate which is fully transformed into phosphate is much more reactive component than lithium carbonate. Actually, our previous study has indicated that unreacted lithium carbonate may remain in the phosphate-based reaction mixtures up to $400^{\circ} \mathrm{C}^{23}$. The next endothermic effect in the studied mixtures appears at 264 ${ }^{\circ} \mathrm{C}$ and is accompanied by substantial weight loss. Typically, presence of $\mathrm{ZrOCl}_{2} \cdot 8 \mathrm{H}_{2} \mathrm{O}$ and $\left(\mathrm{NH}_{4}\right)_{2} \mathrm{HPO}_{4}$ in initial mixture results in formation of $\mathrm{NH}_{4} \mathrm{Cl}$ which is indicated by extensive weight loss and endothermic effect at $330-350^{\circ} \mathrm{C}$ associated with decomposition and sublimation of $\mathrm{NH}_{4} \mathrm{Cl}^{23,24}$. However, in present case, the observed endothermic effect is shifted to much lower temperature (minimum at $264^{\circ} \mathrm{C}$ ). In addition, in the case of the formation of $\mathrm{NH}_{4} \mathrm{Cl}$, the effect of elimination of ammonia of $\left(\mathrm{NH}_{4}\right)_{2} \mathrm{HPO}_{4}$ which appeared at 181-201 ${ }^{\circ} \mathrm{C}$ should be absent because of its reaction with $\mathrm{ZrOCl}_{2} \cdot 8 \mathrm{H}_{2} \mathrm{O}$ producing $\mathrm{NH}_{4} \mathrm{Cl}^{23}$. Thus, the effect at $264^{\circ} \mathrm{C}$ can be hardly attributed to decomposition of $\mathrm{NH}_{4} \mathrm{Cl}$. Indeed, with help of XRD analysis it was confirmed that $\mathrm{NH}_{4} \mathrm{Cl}$ has not been formed in the studied mixtures. The sample heated at $250^{\circ} \mathrm{C}$ during $1 \mathrm{~h}$ contained only zirconium oxychloride, zirconium pyrophosphate, lanthanum phosphates and lithium carbonates. Heating at $300{ }^{\circ} \mathrm{C}$ during $1 \mathrm{~h}$ produced mainly $\mathrm{ZrP}_{2} \mathrm{O}_{7}$ with small amount of lanthanum and lithium phosphates and LZP. The results indicate that the endothermic effect with minimum at $264{ }^{\circ} \mathrm{C}$ should correspond to transformation of dehydrated zirconium oxychloride into the phosphates by its reaction with present phosphate components and lithium carbonate with release of $\mathrm{HCl}, \mathrm{CO}_{2}$ and $\mathrm{NH}_{3}$. Thus, the reaction path in present case is very different from those observed for a similar reaction mixture corresponding to the pure LZP phase in our previous study ${ }^{23}$. The main difference between the initial mixtures for the formation of pure LZP and substituted one is presence of $\mathrm{La}_{2}\left(\mathrm{CO}_{3}\right)_{3} \cdot \mathrm{XH}_{2} \mathrm{O}$. Thus, in spite of the low content of $\mathrm{La}_{2}\left(\mathrm{CO}_{3}\right)_{3} \cdot \mathrm{xH}_{2} \mathrm{O}$ in the initial reaction mixtures, it is a very reactive component able to change the whole reaction path. Further increase of the temperature lead to continuation of the reaction between formed $\mathrm{ZrP}_{2} \mathrm{O}_{7}$, lanthanumand lithium phosphates leading to the formation of LZP phase. In general, it can be concluded, that the studied reaction mixtures corresponding either to $\mathrm{Li}_{0.7} \mathrm{La}_{0.1} \mathrm{Zr}_{2}\left(\mathrm{PO}_{4}\right)_{3}$ or $\mathrm{Li}_{1.1} \mathrm{Zr}_{1.9} \mathrm{La}_{0.1}\left(\mathrm{PO}_{4}\right)_{3}$ composition do not provide direct formation of the La-substituted LZP phases by solid state reaction.

The PM precursors that were subjected to TA consisted of amorphous black solid powders pre-treated at $250^{\circ} \mathrm{C}$ during $12 \mathrm{~h}$. Its colour indicates that during drying not only dehydration but also pyrolysis of the organic polymer has occurred. The results of TA of the precursors of different composition were identical to each other, therefore the results of only one of the mixtures corresponding to $\mathrm{Li}_{0.7} \mathrm{La}_{0.1} \mathrm{Zr}_{2}\left(\mathrm{PO}_{4}\right)_{3}$ are shown in Fig. 1 (PM, Li $\left.\mathrm{Li}_{0.7} \mathrm{La}_{0.1} \mathrm{Zr}_{2}\left(\mathrm{PO}_{4}\right)_{3}\right)$. According to the results, no low-temperature effects connected with dehydration appeared, which indicates that the samples were well dried. An intensive weight loss of $46.5 \%$ accompanied by exothermic DSC effect appears in the temperature range of $300-600^{\circ} \mathrm{C}$. It can be attributed to the process of decomposition/pyrolysis of the organic polymer that initiated interaction in the mixture. The first crystalline products appeared only after prolonged treatment at $600{ }^{\circ} \mathrm{C}$ that 
corresponded to single-phase low crystalline LZP phases. Thus, it can be concluded that the formation of the La-substituted LZP phase takes place directly from PM precursors without formation of intermediate products like in the case of SSR.

Further transformation of the reaction products under prolonged treatment at high temperatures was studied by XRD analysis. Moreover, XRD analysis helped to distinguish which exact type of Lasubstituted LZP structure was formed in the mixtures. According to the previous reports, the symmetry of LZP crystal structure depends on the method of preparation, in particular, presence of moisture and processing temperature, that determine extends of $\mathrm{Li}^{+}$deficiency in the structure ${ }^{7,25}$. Even within not substituted $\mathrm{LiZr}_{2}\left(\mathrm{PO}_{4}\right)_{3}$ composition, LZP is known to exhibit a complex polymorphism: it can adopt the hexagonal, rhombohedral NASICON, triclinic NASICON, orthorhombic SW (Scandium Wolframate) or monoclinic SW structure type depending on the synthesis conditions and temperature ${ }^{7,8,25-29}$. What concerns the solid solutions on basis of Lasubstituted LZP, within the studied substitution rate $(x=0.1)$ it may adopt either the structure type of $\mathrm{Li}_{0.7} \mathrm{La}_{0.1} \mathrm{Zr}_{2}\left(\mathrm{PO}_{4}\right)_{3}$ (triclinic symmetry) or $\mathrm{R}-3 \mathrm{c} \mathrm{LiZr}_{2}\left(\mathrm{PO}_{4}\right)_{3}$ (rhombohedral NASICON-like high ionic conductive structure). Accordingly, detection of $\mathrm{Li}_{0.7} \mathrm{La}_{0.1} \mathrm{Zr}_{2}\left(\mathrm{PO}_{4}\right)_{3}$ (ICDD 01-076-4033 marked as Li/La-LZP) or R-3C $\operatorname{LiZr}_{2}\left(\mathrm{PO}_{4}\right)_{3}$ (ICDD 01-072-7743 marked as $\mathrm{Zr} / \mathrm{La}$-LZP) in phase composition, identified realisation either of $\mathrm{Li}_{1-3 x} \mathrm{La}_{x} \mathrm{Zr}_{2}\left(\mathrm{PO}_{4}\right)_{3}$ or $\mathrm{Li}_{1+\mathrm{x}} \mathrm{Zr} \mathrm{r}_{2-\mathrm{x}} \mathrm{La}_{\mathrm{x}}\left(\mathrm{PO}_{4}\right)_{3}$ substitution model, respectively; while $\beta$ $\operatorname{LiZr}_{2}\left(\mathrm{PO}_{4}\right)_{3}$ ( $\beta$-LZP, ICDD 01-070-5819) is considered as not modified LZP phase intolerable to La-doping. The results of XRD analysis for the samples obtained by SSR and PM with different calcination temperatures are presented in Fig. $2 \mathrm{a}$ and $2 \mathrm{~b}$, respectively, and also are summarised in Table 2.

In case of SSR, for both compositions $\left(\mathrm{Li}_{0.7} \mathrm{La}_{0.1} \mathrm{Zr}_{2}\left(\mathrm{PO}_{4}\right)_{3}\right.$ and $\left.\mathrm{Li}_{1.1} \mathrm{Zr}_{1.9} \mathrm{La}_{0.1}\left(\mathrm{PO}_{4}\right)_{3}\right)$ after the first calcination step at $600{ }^{\circ} \mathrm{C}$, the main crystalline phase corresponded to $\mathrm{ZrP}_{2} \mathrm{O}_{7}$ (ICDD 01-073-2296). $\mathrm{ZrP}_{2} \mathrm{O}_{7}$ was formed in the mixture with $\mathrm{ZrO}_{2}$ (ICDD 01-071-4810), $\mathrm{LaLi}\left(\mathrm{PO}_{3}\right)_{4}$ (ICDD 01-073-2296) and insignificant amount of Li/La-LZP (Fig. 2, 600 ${ }^{\circ} \mathrm{C}$ ). An additional phase of lithium phosphate $\mathrm{LiPO}_{3}$ (ICDD 01-0705642) was also detected by corresponding reflections at $16.3,18.8$ and 25.1 degrees 2 theta in $\mathrm{Li}_{1.1} \mathrm{Zr}_{1.9} \mathrm{La}_{0.1}\left(\mathrm{PO}_{4}\right)_{3}$, which correlates well with the fact of higher initial content of $L i$ in this sample. At higher temperatures, the phase composition of both samples transformed to the mixture of LZP phases with impurity of $\mathrm{LaPO}_{4}$ (ICDD 01-0830651) and another modification of $\mathrm{ZrO}_{2}$ (ICDD 00-037-1484). Thus, Tazheranite modification of $\mathrm{ZrO}_{2}$ has fully disappeared in both compositions after calcination at $1000^{\circ} \mathrm{C}$, while Baddeleyite modification formed at the temperatures above $1300{ }^{\circ} \mathrm{C}$. What concerns $\mathrm{ZrP}_{2} \mathrm{O}_{7}$, for the sample with higher $\mathrm{Zr}$ content (a) SSR

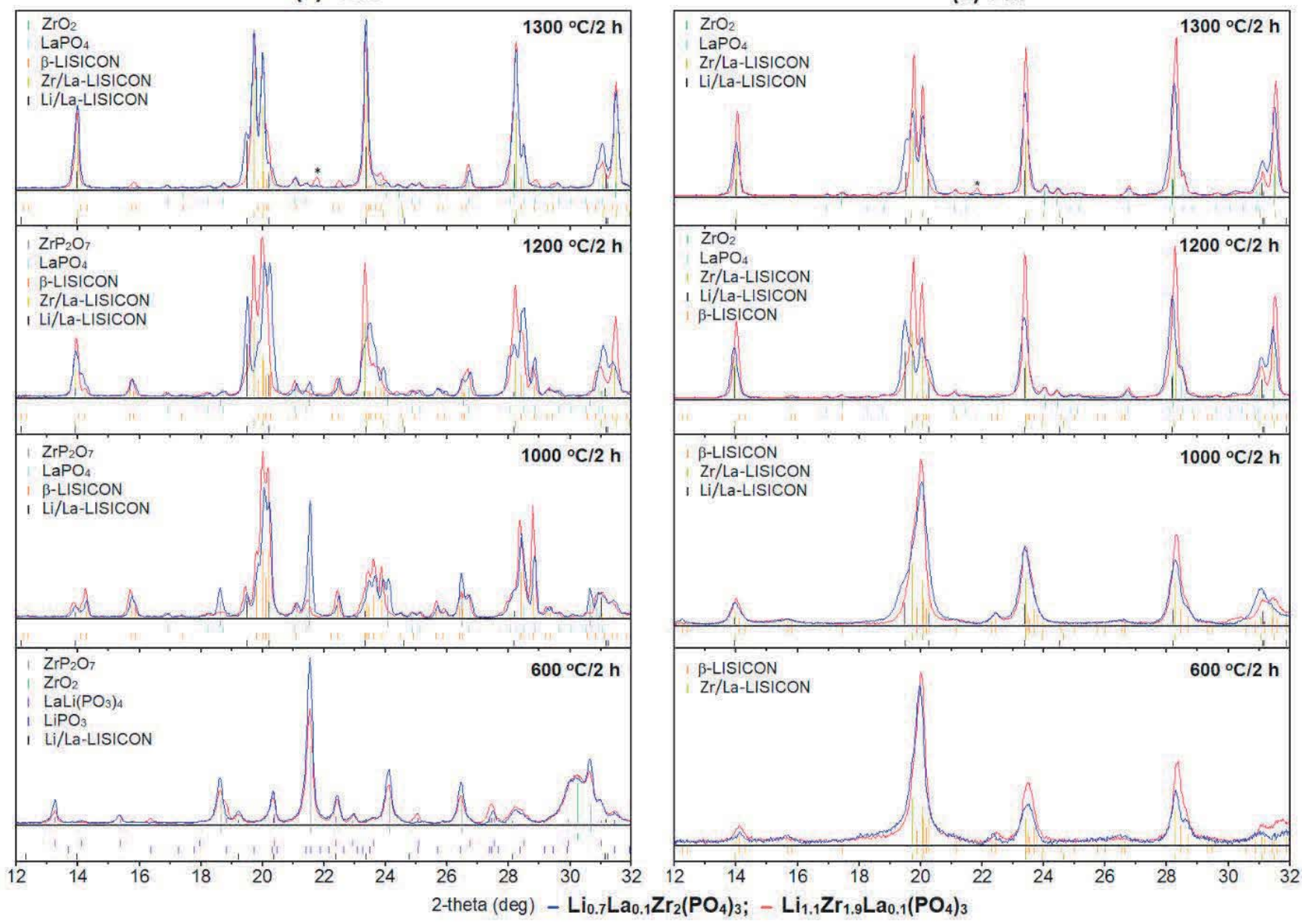

Fig. 2. Phase composition of the samples with chemical composition $\mathrm{Li}_{0.7} \mathrm{La}_{0.1} \mathrm{Zr}_{2}\left(\mathrm{PO}_{4}\right)_{3}$ (in blue) and $\mathrm{Li}_{1.1} \mathrm{Zr}_{1.9} \mathrm{La}_{0.1}\left(\mathrm{PO}_{4}\right)_{3}$ (in red) prepared by SSR (a) and PM (b) in the temperature range of $600-1400^{\circ} \mathrm{C}$. 
Table 2. Phase composition of the samples with chemical composition $\mathrm{Li}_{0.7} \mathrm{La}_{0.1} \mathrm{Zr}_{2}\left(\mathrm{PO}_{4}\right)_{3}$ and $\mathrm{Li}_{1.1} \mathrm{Zr}_{1.9} \mathrm{La}_{0.1}\left(\mathrm{PO}_{4}\right)_{3}$ prepared by $\mathrm{PM}$ and SSR in the temperature range of $600-1400^{\circ} \mathrm{C}$.

\begin{tabular}{|c|c|c|c|c|c|}
\hline \multicolumn{2}{|c|}{ Annealing conditions } & \multicolumn{2}{|l|}{$\mathrm{Li}_{0.7} \mathrm{La}_{0.1} \mathrm{Zr}_{2}\left(\mathrm{PO}_{4}\right)_{3}$} & \multicolumn{2}{|l|}{$\mathrm{Li}_{1.1} \mathrm{Zr}_{1.9} \mathrm{La}_{0.1}\left(\mathrm{PO}_{4}\right)_{3}$} \\
\hline Temperature, ${ }^{\circ} \mathrm{C}$ & Time, $\mathrm{h}$ & PM & SSR & PM & SSR \\
\hline 600 & 2 & Zr/La-LZP; $\beta$-LZP & $\begin{array}{l}\mathrm{ZrP}_{2} \mathrm{O}_{7} ; \mathrm{ZrO}_{2} ; \mathrm{LaLi}\left(\mathrm{PO}_{3}\right)_{4} ; \\
\mathrm{Li} / \mathrm{La}-\mathrm{LZP}\end{array}$ & Zr/La-LZP; $\beta$-LZP & $\begin{array}{l}\mathrm{ZrP}_{2} \mathrm{O}_{7} ; \mathrm{ZrO}_{2} ; \mathrm{LaLi}\left(\mathrm{PO}_{3}\right)_{4} ; \\
\mathrm{Li} / \mathrm{La}-\mathrm{LZP} ; \mathrm{LiPO}_{3}\end{array}$ \\
\hline 800 & 2 & \multirow{3}{*}{$\begin{array}{l}\text { Li/La-LZP; Zr/La-LZP; } \\
\beta \text {-LZP }\end{array}$} & \multirow{3}{*}{$\begin{array}{l}\beta-\mathrm{LZP} ; \mathrm{Li} / \mathrm{La}-\mathrm{LZP} ; \mathrm{ZrP}_{2} \mathrm{O}_{7} ; \\
\mathrm{LaPO}_{4}\end{array}$} & \multirow[t]{3}{*}{ Zr/La-LZP; $\beta$-LZP } & \multirow{3}{*}{$\begin{array}{l}\beta \text {-LZP; Li/La-LZP; } \mathrm{LaPO}_{4} \\
\mathrm{ZrP}_{2} \mathrm{O}_{7}\end{array}$} \\
\hline 1000 & $2-12$ & & & & \\
\hline 1100 & 2 & & & & \\
\hline 1200 & $2-12$ & $\begin{array}{l}\text { Li/La-LZP; Zr/La-LZP; } \\
\mathrm{LaPO}_{4} ; \mathrm{ZrO}_{2}\end{array}$ & $\begin{array}{l}\text { Li/La-LZP; Zr/La-LZP; } \beta \text {-LZP; } \\
\mathrm{ZrP}_{2} \mathrm{O}_{7} ; \mathrm{LaPO}_{4}\end{array}$ & $\begin{array}{l}\text { Li/La-LZP; Zr/La-LZP; } \\
\beta \text {-LZP; } \mathrm{LaPO}_{4} ; \mathrm{ZrO}_{2}\end{array}$ & $\begin{array}{l}\text { Zr/La-LZP; } \beta \text {-LZP; Li/La-LZP; } \\
\mathrm{LaPO}_{4}\end{array}$ \\
\hline 1300 & $2-24$ & \multirow{2}{*}{$\begin{array}{l}\text { Li/La-LZP; Zr/La-LZP; } \\
\mathrm{LaPO}_{4} ; \mathrm{ZrO}_{2}\end{array}$} & \multirow{2}{*}{$\begin{array}{l}\mathrm{Li} / \mathrm{La}-\mathrm{LZP} ; \mathrm{Zr} / \mathrm{La}-\mathrm{LZP} ; \mathrm{LaPO}_{4} \\
\mathrm{ZrO}_{2}\end{array}$} & \multirow{2}{*}{$\begin{array}{l}\mathrm{Zr} / \mathrm{La}-\mathrm{LZP} ; \mathrm{LaPO}_{4} ; \mathrm{ZrO}_{2} ; \\
\text { unknown }\end{array}$} & \multirow{2}{*}{$\begin{array}{l}\text { Li/La-LZP; Zr/La-LZP; } \beta \text {-LZP; } \\
\mathrm{LaPO}_{4} ; \mathrm{ZrO}_{2} ; \text { unknown }\end{array}$} \\
\hline 1400 & $2-48$ & & & & \\
\hline
\end{tabular}

$\left(\mathrm{Li}_{0.7} \mathrm{La}_{0.1} \mathrm{Zr}_{2}\left(\mathrm{PO}_{4}\right)_{3}\right)$, it was still clearly observed after calcination at $1200^{\circ} \mathrm{C}$. In this sample it got fully reacted only after prolonged calcination at $1300^{\circ} \mathrm{C}$; for another sample with lower $\mathrm{Zr}$ content $\left(\mathrm{Li}_{1.1} \mathrm{Zr}_{1.9} \mathrm{La}_{0.1}\left(\mathrm{PO}_{4}\right)_{3}\right), \mathrm{ZrP}_{2} \mathrm{O}_{7}$ got fully reacted already below $1200{ }^{\circ} \mathrm{C}$. An unknown phase was also detected in $\mathrm{Li}_{1.1} \mathrm{Zr}_{1.9} \mathrm{La}_{0.1}\left(\mathrm{PO}_{4}\right)_{3}$ sample after high-temperature treatment (marked by * in Fig. $2 \mathrm{a}, 1300^{\circ} \mathrm{C}$ ). The main high-temperature solid state reaction product for both compositions are the LZPs. The sample $\mathrm{Li}_{0.7} \mathrm{La}_{0.1} \mathrm{Zr}_{2}\left(\mathrm{PO}_{4}\right)_{3}$ after calcination at $1300-1400{ }^{\circ} \mathrm{C}$ contained a mixture of 2 substituted LZP phases (Li/La-LZP and Zr/La-LZP). With increase of the calcination temperature from 1200 to $1300^{\circ} \mathrm{C}$, the relative content of Li/La-LZP in this sample has clearly reduced in comparison to $\mathrm{Zr} / \mathrm{La}-\mathrm{LZP}$, which increased. Undoped $\beta$-LZP, which was present in $\mathrm{Li}_{0.7} \mathrm{La}_{0.1} \mathrm{Zr}_{2}\left(\mathrm{PO}_{4}\right)_{3}$ sample at lower temperatures, was fully transformed into Lasubstituted LZPs that is indicated by the absence of the typical $\beta$-LZP reflections at 15.7-15.8 degrees 2 theta. On opposite, the sample $\mathrm{Li}_{1.1} \mathrm{Zr}_{1.9} \mathrm{La}_{0.1}\left(\mathrm{PO}_{4}\right)_{3}$ treated at $1300-1400^{\circ} \mathrm{C}$ contained the main phase of La-substituted Zr/La-LZP with impurity of undoped $\beta$-LZP. As an intermediate product at lower temperatures, this sample also contained Li/La-LZP phase, which content was significantly reduced after the treatment at $1200^{\circ} \mathrm{C}$. At the same time, relative content of $\beta$-LZP at lower temperatures was also higher. The result suggests that $\mathrm{Zr} / \mathrm{La}$-LZP is more stable at higher temperatures. Further, calcination at $1400{ }^{\circ} \mathrm{C}$ has not influenced phase composition of the samples and the relative intensity of the reflections of different phases remained the same. It suggests that no reaction between $\mathrm{LaPO}_{4}$ and other phases to form La-substituted LZPs or decomposition of La-LZPs to form $\mathrm{LaPO}_{4}$ and $\beta$-LZP happened. In addition, it is worth to mention that due to the presence of $\mathrm{LaPO}_{4}$ impurity, the real substitution rate achieved for the La-substituted LZPs obtained by SSR should be lower than 0.1 . The failure of SSR to provide the formation of substituted LZPs without other impurities is not surprising at all because even the formation of pure $\mathrm{LiZr}_{2}\left(\mathrm{PO}_{4}\right)_{3}$ by this method requires complex manipulations ${ }^{7}$. Therefore, successful adaptation of the SSR approach for the synthesis of REE-substituted LZPs is not excluded at all.

In case of PM, as it was already mentioned earlier, interaction in the mixture is initiated by exothermic polymer decomposition/pyrolysis, which lead to direct formation of pure LZPs whatever the initial composition was (Fig. $2 \mathrm{~b}, 600^{\circ} \mathrm{C}$ ). Initially, substituted $\mathrm{Zr} / \mathrm{La}$-LZP and undoped $\beta$-LZP can be distinguished in the phase composition of both samples. In addition, Li/La-LZP appeared in the composition of the $\mathrm{Li}_{0.7} \mathrm{La}_{0.1} \mathrm{Zr}_{2}\left(\mathrm{PO}_{4}\right)_{3}$ sample after calcination at $1000^{\circ} \mathrm{C}$. The dominating La-substituted LZP phase in both samples seems to be $\mathrm{Zr} /$ La-LZP. However, with the calcination temperature below $1100{ }^{\circ} \mathrm{C}$, the reflections of LZP phases appeared poorly separated due to low crystallinity that complicated exact identification of the dominating LZP phase in each sample. At higher temperatures, $\beta$-LZP fully transformed into the substituted LZPs, however, small impurities of $\mathrm{ZrO}_{2}$ and $\mathrm{LaPO}_{4}$ appeared in the phase composition of both samples. Similar to the results obtained by SSR, Zr/La-LZP dominated at higher calcination temperatures that testifies in favour of its higher thermal stability. In particular, with the calcination temperature of $1200^{\circ} \mathrm{C}, \mathrm{Zr} / \mathrm{La}$-LZP is the only LZP phase detected in the $\mathrm{Li}_{1.1} \mathrm{Zr}_{1.9} \mathrm{La}_{0.1}\left(\mathrm{PO}_{4}\right)_{3}$ sample. With increase of the calcination temperature, intensity of the reflections corresponding to the impurity phases $\left(\mathrm{ZrO}_{2}\right.$ and $\left.\mathrm{LaPO}_{4}\right)$ did not change, while additional unknown phase similar to those detected in the SSR$\mathrm{Li}_{1.1} \mathrm{Zr}_{1.9} \mathrm{La}_{0.1}\left(\mathrm{PO}_{4}\right)_{3}$ sample appeared after calcination at $1300^{\circ} \mathrm{C}$ (marked by ${ }^{*}$ in Fig. $2 \mathrm{~b}, 1300^{\circ} \mathrm{C}$ ). Thus, it can be concluded that PM allows synthesis of a mixture of LZP phases with the substitution rate of 0.1 with no impurities only at the temperatures below $1100^{\circ} \mathrm{C}$. Formation of $\mathrm{LaPO}_{4}$ impurity above $1000{ }^{\circ} \mathrm{C}$ also suggests that the tolerance towards substitution is decreased below 0.1 at higher temperatures. It should be also noticed, that PM synthesis approach at lower temperatures also does not provide the formation of the pure phase products corresponding either to $\mathrm{Li}_{1-3 \mathrm{x}} \mathrm{La}_{\mathrm{x}} \mathrm{Zr}_{2}\left(\mathrm{PO}_{4}\right)_{3}$ or $\mathrm{Li}_{1+x} \mathrm{Zr} \mathrm{r}_{2-x} \mathrm{La}_{x}\left(\mathrm{PO}_{4}\right)_{3}$ substitution models with the substitution degree 0.1 but the mixture of these phases with $\beta$-LZP. Thus, our study confirms the possibility of realisation of the both substitution models however the solid solutions can be obtained only in mixture with $\beta$ LZP or/and with each other whatever the composition of the initial mixture is.

The formation of the impurities in LZP samples has been explained in the previous studies by Li loss during treatment ${ }^{7,25}$. Accordingly, it has been shown that high temperature treatment lead to $\mathrm{Li}^{+}$ deficiency in the LZP structure which can be compensated by Li excess (up to $20 \%$ ) in the initial mixture. We have tried this approach too, however for the samples calcined at $1200^{\circ} \mathrm{C}$ and higher, the excessive content of $\mathrm{Li}$ in the initial mixture lead to higher impurities content, in particular of $\mathrm{LaPO}_{4}$. Substantial increase of the relative intensities corresponding to $\mathrm{LaPO}_{4}$ reflections was observed when the lithium excess reached $20 \%$. The result suggests that the Li atoms compensate charge deficiency more effectively than La and could replace it out of the LZP structure in both substitution models. The discrepancy between our results and the previous studies that report realisation of the targeted substitution models in pure state $^{9,10,14,16,17}$ may be explained by the fact, that the discussed LZPrelated structures are crystallographically close to each other and under certain conditions it could be difficult to distinguish the formation of mixed phase compounds. In particular, while the formation of $\beta$-LZP is clearly indicated by characteristic reflections (15.7-15.8 degrees 2 theta), the reflections of Li/La-LZP and Zr/La-LZP are very close to each other and can be distinguished only in well- 
crystalline samples with high resolution XRD. Therefore, a careful attention should be paid to phase identification of REE-substituted LZP phases where possible appearance of different substitution models that affect the sample properties should be taken into account.

On basis of these results, the synthesis approach on basis of PM was employed for the preparation of series of REE-substituted LZPs corresponding to two substitution models with REE content 0.1. For each REE, two initial compositions corresponding to two substitution models of $\mathrm{Li}_{0.7} \mathrm{REE}_{0.1} \mathrm{Zr}_{2}\left(\mathrm{PO}_{4}\right)_{3}$ and $\mathrm{Li}_{1.1} \mathrm{Zr}_{1.9} \mathrm{REE}_{0.1}\left(\mathrm{PO}_{4}\right)_{3}$, where REE is $\mathrm{Y}, \mathrm{La}, \mathrm{Ce}, \mathrm{Pr}, \mathrm{Nd}, \mathrm{Sm}, \mathrm{Eu}, \mathrm{Gd}, \mathrm{Tb}, \mathrm{Dy}, \mathrm{Ho}, \mathrm{Er}, \mathrm{Tm}, \mathrm{Yb}$ or Lu, were studied. Effect of the initial composition was evaluated with focus on the phase composition, optical absorption properties, sintering degree, particle size etc.

The results of XRD analysis confirmed the formation of the mixture of LZP phases. Similar to La-substituted LZPs, after calcination at 1000 ${ }^{\circ} \mathrm{C}$ the samples with initial composition of $\mathrm{Li}_{0.7} \mathrm{REE}_{0.1} \mathrm{Zr}_{2}\left(\mathrm{PO}_{4}\right)_{3}$ contained three LZP phases (Zr/REE-LZP, Li/REE LZP and $\beta$-LZP), while $\mathrm{Li}_{1.1} \mathrm{Zr}_{1.9} \mathrm{REE}_{0.1}\left(\mathrm{PO}_{4}\right)_{3}$ - only two (Zr/REE-LZP and $\beta$-LZP). Further increase of the calcination temperature lead to the formation of impurities ((REE)PO $\mathrm{PO}_{4}$ and $\left.\mathrm{ZrO}_{2}\right)$. Therefore, for the following investigation of optical absorption properties, the samples were synthesised using the calcination temperature of $1000^{\circ} \mathrm{C}$.

\section{Optical properties of REE-substituted $\operatorname{LiZr}_{2}\left(\mathrm{PO}_{4}\right)_{3}$}

In order to evaluate the value of the samples for pigment application, colour properties of the two series of REE-LZPs were calculated on basis of the diffuse reflectance of the powders in VIS region of light. Prior to the colour measurement, the mean particle size distribution of the samples was evaluated to be in range of $2,28-5,47 \mu \mathrm{m}$ that exclude the possibility of particle size impact on the samples reflectance properties. Next, on basis of the reflectance spectra of the powders in the visible region of light $(400-700 \mathrm{~nm})$, the following colour parameters were calculated: $a^{*}$ and $b^{*}$ which indicate the colour shade (colour hue $h^{\circ}=\operatorname{arctangent}\left(b^{*} \cdot a^{*-1} \cdot 360^{\circ} \cdot(2 \cdot 3.14)^{-1}\right)$ and the colour saturation (chroma $\left.C^{*}=\left(a^{* 2}+b^{* 2}\right)^{0.5}\right) ; L^{*}$ which represents the lightness or darkness of colour as related to a neutral grey scale and is described by numbers from 0 (black) to 100 (white).The total colour difference between pure LZP and the REELZP was calculated according to the formula: $d E=\left(d L^{* 2}+d a^{* 2}+\right.$ $\left.d b^{* 2}\right)^{0.5}$ ). The colour parameters of pure LZP were determined as follows: $a^{*}=0.4, b^{*}=2.5, L^{*}=95.4, h^{\circ}=81.1, C^{*}=2.5$, white colour. The calculated $a^{*}$ and $b^{*}$ colour parameters of all samples are presented in Fig. 3 ( $a^{*}$ corresponds to abscissa that represents the green $(-) \rightarrow$ red $(+)$ axis; $b^{*}$ corresponds to ordinate that represents the blue $(-) \rightarrow$ yellow (+) axis). The fig. 3 also shows lightness and saturation parameters of the samples, the values for REE $=Y$-Lu (i.e. $\mathrm{Y}, \mathrm{La}, \mathrm{Ce}, \mathrm{Sm}, \mathrm{Eu}, \mathrm{Gd}, \mathrm{Dy}, \mathrm{Er}, \mathrm{Tm}, \mathrm{Yb}$ or $\mathrm{Lu}$ ) are combined in circle as being very close to each other within both substitution models. All calculated colour parameters of the samples are summarised in detail in Table 3.

As it follows from the presented results, the colour change induced by REE doping is perceptible to the human eye ( $d E$ is above 1 ) in all samples, however due to high lightness $\left(L^{*}=93.1-94.8\right)$, in most cases even in spite of high saturation, it is still perceived as very close to white. In general, only four REEs have significantly affected the colour of the samples mainly with $\mathrm{Li}_{0.7} \mathrm{REE}_{0.1} \mathrm{Zr}_{2}\left(\mathrm{PO}_{4}\right)_{3}$ composition. In particular, for this composition, $\mathrm{Nd}$ has induced purple shade, $\mathrm{Tb}$ yellow, Ho - yellow and $\mathrm{Pr}-$ green. The colour of these samples can be well perceived by human eye also because it is darker and in most cases quite saturated (Fig. 3, Table 3). Among all REEs, Pr is the only element that induced well-visible darker colouration in both
$\Delta L \mathrm{Li}_{0.7} \mathrm{REE}_{0.1} \mathrm{Zr}_{2}\left(\mathrm{PO}_{4}\right)_{3} \quad \square \mathrm{Li}_{1.1} \mathrm{Zr}_{1.9} \mathrm{REE}_{0.1}\left(\mathrm{PO}_{4}\right)_{3}$

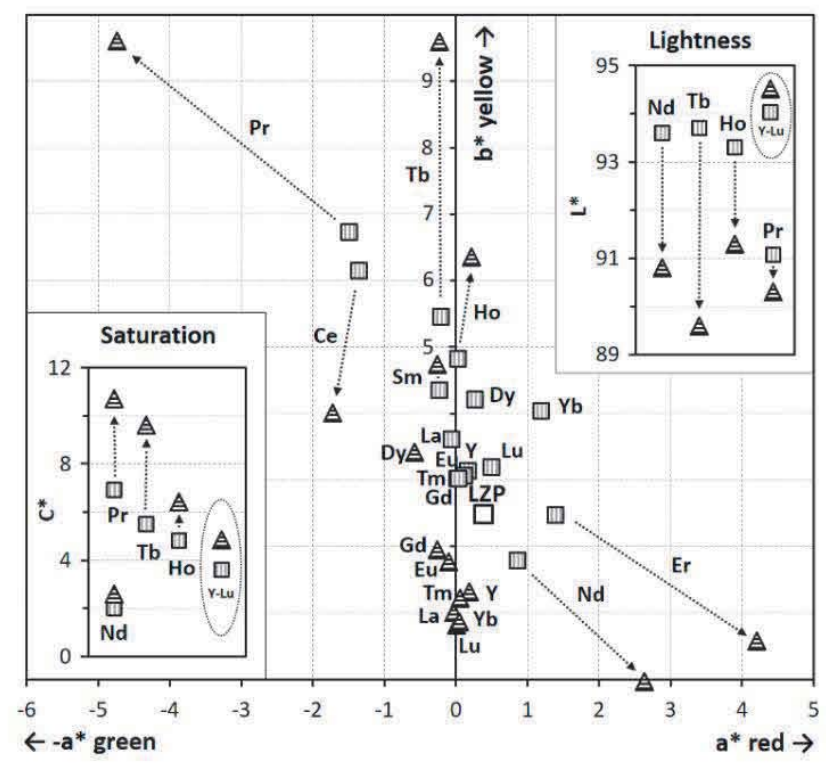

Fig. 3. Colour properties of REE-substituted LZP samples with different composition obtained by PM after calcination at 1000 ${ }^{\circ} \mathrm{C}$ (saturation and lightness values for Y-Lu i.e. Y, La, Ce, Sm, Eu, $\mathrm{Gd}, \mathrm{Dy}, \mathrm{Er}, \mathrm{Tm}, \mathrm{Yb}$ or $\mathrm{Lu}$, are combined).

substitution models, $\mathrm{Li}_{0.7} \mathrm{REE}_{0.1} \mathrm{Zr}_{2}\left(\mathrm{PO}_{4}\right)_{3}$ and $\mathrm{Li}_{1.1} \mathrm{Zr}_{1.9} \mathrm{REE}_{0.1}\left(\mathrm{PO}_{4}\right)_{3}$. In some cases effect of REE on the samples' colouration depended on the composition $\left(\mathrm{Li}_{0.7} \mathrm{REE}_{0.1} \mathrm{Zr}_{2}\left(\mathrm{PO}_{4}\right)_{3}\right.$ or $\left.\mathrm{Li}_{1.1} \mathrm{Zr}_{1.9} \mathrm{REE}_{0.1}\left(\mathrm{PO}_{4}\right)_{3}\right)$ and the source of incident light (daylight or fluorescent lamp). For Ho and Eu, the colour of the samples under the daylight is light yellow or white while under fluorescent light it became more saturated of the pink shade. This phenomenon can be explained with the luminescent properties of REEs.

The origin of colouration of the studied REE-LZP samples can be ascribed to REEs substitution. Similar to $3 d$ metals, REEs act as chromophore that partially absorbs light in VIS range due to electronic transitions of $4 \mathrm{f}$ electrons. Effect of the substitution model on the colour properties of the samples is connected to the phase composition, in particular the crystalline structure which prevails in each particular case. According to the crystal field theory, which can be applied to solid polycrystalline phosphates, the colour of the samples depends on crystallographic environment of the REEs in LZP structure, which is different in the considered substitution models. In particular, in $\mathrm{Li}_{1.1} \mathrm{Zr}_{1.9} \mathrm{REE}_{0.1}\left(\mathrm{PO}_{4}\right)_{3}$, REEs occupy tight octahedral $\mathrm{Zr}$ positions, while in $\mathrm{Li}_{0.7} \mathrm{REE}_{0.1} \mathrm{Zr}_{2}\left(\mathrm{PO}_{4}\right)_{3}$ REEs are located in structural cavities (channels) of irregular geometry with 6 or more oxygen atoms in the nearest environment ${ }^{30}$. In view that the proportion of the phases corresponding to different substitution models within the samples varies, therefore, in some cases the resultant colour is different not only in the view of lightness, but also colour shade. In particular, the colour shade has significantly varied with $\mathrm{REE}=\mathrm{La}, \mathrm{Nd}$ and $\mathrm{Ce}$ which is indicated by significant change of colour hue $\left(\mathrm{h}^{\circ}\right)$ of the corresponding samples (Table 3).

In general, colour of the REE-LZP samples (where REE $=\mathrm{Nd}$, Tb, Ho or $\mathrm{Pr}$ ) is lower in saturation and higher in lightness in comparison to other ceramic pigments based on 3d metal phosphates ${ }^{2,31-38}$. However, the content of chromophore in the studied samples (REE) is substantially lower than those in individual complex $3 \mathrm{~d}$ metal phosphates. If to compare the studied samples with analogous solid 
Table 3. Colour properties of the REE-substituted LZP samples with different composition obtained by PM after calcination at $1000{ }^{\circ} \mathrm{C}$.

\begin{tabular}{|l|l|l|l|l|l|l|l|l|l|l|l|l|l|l|}
\hline $\mathrm{Li}_{0.7} \mathrm{REE}_{0.1} \mathrm{Zr}_{2}\left(\mathrm{PO}_{4}\right)_{3}$ & \multicolumn{10}{|l|}{$\mathrm{Li}_{1.1} \mathrm{Zr}_{1.9} \mathrm{REE}_{0.1}\left(\mathrm{PO}_{4}\right)_{3}$} \\
\hline $\mathrm{REE}$ & $\mathrm{a}^{*}$ & $\mathrm{~b}^{*}$ & $\mathrm{~L}^{*}$ & $\mathrm{~h}^{\circ}$ & $\mathrm{C}^{*}$ & $d E$ & Colour & $\mathrm{a}^{*}$ & $\mathrm{~b}^{*}$ & $\mathrm{~L}^{*}$ & $\mathrm{~h}^{\circ}$ & $\mathrm{C}^{*}$ & $d E$ & $\mathrm{Colour}$ \\
\hline $\mathrm{Y}$ & 0.2 & 1.3 & 94.6 & 81.8 & 1.3 & 1.4 & white & 0.2 & 3.1 & 94 & 87 & 3.1 & 1.6 & white \\
\hline $\mathrm{La}$ & 0 & 1 & 93.1 & 271.7 & 1 & 2.8 & white & -0.1 & 3.6 & 93.1 & 91 & 3.6 & 2.6 & white \\
\hline $\mathrm{Ce}$ & -1.7 & 4 & 93.6 & 113.2 & 4.4 & 3.2 & white & -1.4 & 6.2 & 94.1 & 102.4 & 6.3 & 4.3 & white \\
\hline $\mathrm{Pr}$ & -4.7 & 9.6 & 90.3 & 116.3 & 10.7 & 10.2 & green & -1.5 & 6.7 & 91.1 & 102.5 & 6.9 & 6.3 & green \\
\hline $\mathrm{Nd}$ & 2.6 & -0.1 & 90.8 & 358.9 & 2.6 & 5.7 & purple & 0.9 & 1.8 & 93.6 & 64.2 & 2 & 2 & white \\
\hline $\mathrm{Sm}$ & -0.3 & 4.7 & 94 & 93.1 & 4.7 & 2.7 & white & -0.2 & 4.3 & 94 & 93.1 & 4.4 & 2.4 & white \\
\hline $\mathrm{Eu}$ & -0.1 & 1.8 & 94.6 & 93.2 & 1.8 & 1.2 & white & 0.1 & 3.1 & 94.1 & 87.8 & 3.1 & 1.5 & white \\
\hline $\mathrm{Gd}$ & -0.3 & 2 & 94.6 & 97.6 & 2 & 1.1 & white & 0 & 3 & 94.2 & 89.7 & 3 & 1.4 & white \\
\hline $\mathrm{Tb}$ & -0.2 & 9.6 & 89.6 & 91.3 & 9.6 & 9.2 & yellow & -0.2 & 5.5 & 93.7 & 92.1 & 5.5 & 3.5 & white \\
\hline $\mathrm{Dy}$ & -0.6 & 3.4 & 94.5 & 99.6 & 3.5 & 1.6 & white & 0.3 & 4.2 & 93.8 & 86.4 & 4.2 & 2.4 & white \\
\hline $\mathrm{Ho}$ & 0.2 & 6.4 & 91.3 & 88.1 & 6.4 & 5.6 & yellow & 0 & 4.8 & 93.3 & 89.8 & 4.8 & 3.2 & white \\
\hline $\mathrm{Er}$ & 4.2 & 0.6 & 94.1 & 7.8 & 4.2 & 4.5 & white & 1.4 & 2.5 & 93.5 & 60.7 & 2.8 & 2.1 & white \\
\hline $\mathrm{Tm}$ & 0 & 0.8 & 94.7 & 89.3 & 0.8 & 1.9 & white & 0 & 3 & 94.1 & 89.3 & 3 & 1.5 & white \\
\hline $\mathrm{Yb}$ & 0.1 & 1.2 & 94.8 & 87.2 & 1.2 & 1.4 & white & 1.2 & 4 & 94.2 & 73.6 & 4.2 & 2.1 & white \\
\hline $\mathrm{Lu}$ & 0.1 & 0.9 & 95.2 & 86.7 & 0.9 & 1.7 & white & 0.5 & 3.2 & 94.1 & 81.3 & 3.2 & 1.4 & white \\
\hline
\end{tabular}

${ }^{1}$ colour shade changes to pink in fluorescent light

solutions of $\mathrm{Cr}(\mathrm{III})$, at the same substitution range $(\mathrm{x}=0.1)$ the colour parameters of $\mathrm{Cr}$-containing samples is comparable or even less attractive than those of REE-containing samples ${ }^{2}$. In particular, $\mathrm{Li}_{1.1} \mathrm{Cr}_{0.1} \mathrm{Zr}_{1.9}\left(\mathrm{PO}_{4}\right)_{3}$ was characterised with lightness of 88.5 and saturation of 5.7, while colour saturation above 10 is reached in these series only for the $\mathrm{Cr}(\mathrm{III})$ molar content above 1 (corresponds to composition $\left.\mathrm{Li}_{2.1} \mathrm{Cr}_{1.1} \mathrm{Zr}_{0.9}\left(\mathrm{PO}_{4}\right)_{3}\right)$. Theoretically, $\mathrm{REE}$ could provide even more intense colouration at higher concentrations, however in the case of LZP structure, its content is limited due to the narrow substitution range. It can be concluded that REE substitution can be considered in line with $3 \mathrm{~d}$ metal substitution as an alternative approach to modification of white phosphate ceramics in order to achieve attractive colouration for pigment application. Additional advantage of REE in comparison to $3 \mathrm{~d}$ metals can be attributed to colour sensitivity to ambient light attributed to luminescent properties of REEs.

\section{Conclusions}

In our study, the concept of the formation of the solid solutions according to different substitution models $\left(\mathrm{Li}_{1-3 x} \mathrm{La}_{x} \mathrm{Zr}_{2}\left(\mathrm{PO}_{4}\right)_{3}\right.$ and $\left.\mathrm{Li}_{1+x} \mathrm{Zr}_{2-\mathrm{x}} \mathrm{La}_{\mathrm{x}}\left(\mathrm{PO}_{4}\right)_{3}\right)$ has been verified using two synthesis approaches: a polymerizable-complex method based on Pechini method (PM) and a solid state reaction (SSR). The substitution degree $x$ in both models was limited to 0.1 giving $\mathrm{Li}_{0.7} \mathrm{La}_{0.1} \mathrm{Zr}_{2}\left(\mathrm{PO}_{4}\right)_{3}$ corresponding to triclinic LZP and $\mathrm{Li}_{1.1} \mathrm{Zr}_{1.9} \mathrm{La}_{0.1}\left(\mathrm{PO}_{4}\right)_{3}$ corresponding to NASICON-like high ion conductive rhombohedral LZP. Formation of the different REE-LZP compounds can be distinguished in well crystalline powders by high resolution XRD analysis.

Our results indicate that the both substitution models can be realised, however within the studied synthesis routes it is impossible to obtain the substituted structures of particular type in pure state. The preferable method for the synthesis of REE-substituted LZP is PM which allows synthesis of a mixture of LZP phases with the substitution rate of 0.1 with no impurities at the temperatures below $1100^{\circ} \mathrm{C}$. At higher temperatures, the substituted LZPs are less stable and additional impurities of $\mathrm{LaPO}_{4}$ and $\mathrm{ZrO}_{2}$ are formed. It is shown that $\mathrm{Li}_{1+\mathrm{X}} \mathrm{Zr}_{2-\mathrm{x}} \mathrm{La}_{\mathrm{x}}\left(\mathrm{PO}_{4}\right)_{3}$ model has higher thermal stability and this phase prevails at the temperatures above $1200{ }^{\circ} \mathrm{C}$. However, the tolerance towards substitution in both substitution models is decreased below 0.1 above $1000{ }^{\circ} \mathrm{C}$ that results in the formation of $\mathrm{LaPO}_{4}$ impurity. Moreover, it is shown that Li excess in initial mixture, typically used to achieve the formation of pure phase LZP product, in the studied conditions induced REE replacement off the LZP structure producing (REE) $\mathrm{PO}_{4}$ phase.

The Pechini method was applied to the whole series of REEs in order to obtain REE-substituted $\mathrm{LiZr}_{2}\left(\mathrm{PO}_{4}\right)_{3}$ and to verify their optical properties for pigment application. Similar to La-LZPs, after calcination at $1000^{\circ} \mathrm{C}$ the samples with initial composition of $\mathrm{Li}_{0.7} \mathrm{REE}_{0.1} \mathrm{Zr}_{2}\left(\mathrm{PO}_{4}\right)_{3}$ contained three LZP phases ( $\mathrm{Zr} / \mathrm{La}-\mathrm{LZP}$, Li/La LZP and $\beta$-LZP), while $\mathrm{Li}_{1.1} \mathrm{Zr}_{1.9} \mathrm{REE}_{0.1}\left(\mathrm{PO}_{4}\right)_{3}$ - only two (Zr/La-LZP and $\beta$-LZP). Among the studied samples, only four REEs ( $\mathrm{Nd}, \mathrm{Tb}, \mathrm{Ho}$ and $\mathrm{Pr}$ ) provide attractive colouration that varies from purple, yellow to green shades and depends on the crystal structure of prevailing REE-LZP phase in the product. Our study confirms that REE substitution can be considered as alternative approach to modification of white phosphate ceramics to induce attractive colouration which additional advantage consists in colour sensitivity to ambient light attributed to luminescent properties of REEs.

In general, it can be concluded that a very careful attention should be paid to phase identification of REE-substituted LZP phases where possible appearance of different substitution models that affect the sample properties should be taken into account.

\section{Conflicts of interest}

There are no conflicts to declare.

\section{References}

1 N. Wu, P.-H. Chien, Y. Li, A. Dolocan, H. Xu, B. Xu, N. S. Grundish, H. Jin, Y.-Y. Hu and J. B. Goodenough, J. Am. Ceram. Soc., 2020, 142, 2497-2505. 
2 N. Gorodylova, V. Kosinová and P. Šulcová, Ceram. Int., 2017, 43, 14629-14635.

3 A. B. Ilyin, M. M. Ermilova, N. V. Orekhova and A. B. Yaroslavtsev, Nanotechnologies Russ., 2018, 13, 365-371.

4 K. Nakano, Y. Noda, N. Tanibata, H. Takeda, M. Nakayama, R. Kobayashi and I. Takeuchi, APL Mater., 2020, 8, 41112:1-6.

5 D. Mutter, D. F. Urban and C. Elsässer, J. Appl. Phys., 2019, 125, 215115.

6 Y. Li, W. Zhou, X. Chen, X. Lu, Z. Cui, S. Xin, L. Xue, Q. Jia and J. B. Goodenough, Proc. Natl. Acad. Sci. U. S. A., 2016, 113, 1331313317.

7 I. A. Stenina, Y. A. Velikodnyi, V. A. Ketsko and A. B. Yaroslavtsev, Inorg. Mater., 2004, 40, 967-970.

8 M. Casciola, U. Costantino, L. Merlini, I. G. K. Andersen and E. K. Andersen, Solid State lonics, 1988, 26, 229-235.

9 Y. Li, M. Liu, K. Liu and C. A. Wang, J. Power Sources, 2013, 240, 50-53.

10 V. Ramar, S. Kumar, S. R. Sivakkumar and P. Balaya, Electrochim. Acta, 2018, 271, 120-126.

11 D. V. Safronov, I. A. Stenina, A. V. Maksimychev, S. L. Shestakov and A. B. Yaroslavtsev, Russ. J. Inorg. Chem., 2009, 54, 16971703.

12 M. Barré, F. Le Berre, M. P. Crosnier-Lopez, C. Galven, O. Bohnké and J. L. Fourquet, lonics (Kiel)., 2009, 15, 681-687.

13 H. Xu, S. Wang, H. Wilson, F. Zhao and A. Manthiram, Chem. Mater., 2017, 29, 7206-7212.

14 M. Barré, M. P. Crosnier-Lopez, F. Le Berre, E. Suard and J. L. Fourquet, J. Solid State Chem., 2007, 180, 1011-1019.

15 M. Barré, M. P. Crosnier-Lopez, F. Le Berre, J. Emery, E. Suard and J.-L. Fourquet, Chem. Mater., 2005, 17, 6605-6610.

16 C. R. Mariappan, P. Kumar, A. Kumar, S. Indris, H. Ehrenberg, G. Vijaya Prakash and R. Jose, Ceram. Int., 2018, 44, 15509-15516.

17 J. Z. Sun, J. Chil. Chem. Soc., 2008, 53, 1682-1683.

18 A. I. Orlova, Czechoslov. J. Phys., 2003, 53, A649-A655.

19 R. D. Shannon, Acta Crystallogr., 1976, A32, 751-767.

20 M. Catti, A. Comotti and S. Di Blas, Chem. Mater., 2003, 15, 1628-1632.

21 E. B. Faulkner and R. J. Schwartz, Eds., Introduction to Inorganic High Performance Pigments, Wiley-VCH Verlag GmbH \& Co. KGaA, Weinheim, Germany, Second, Co., 2009.

22 CIE. Recommendations on uniform colour spaces, colour difference equations, psychometrics colour terms., Paris, 1978.

23 N. Gorodylova and P. Šulcová, J. Therm. Anal. Calorim., 2018, 133, 405-411.

24 N. Gorodylova, P. Šulcová, M. Bosacka and E. Filipek, J. Therm. Anal. Calorim., 2014, 118, 1095-1100.

25 W. W. Gould, S. Komarneni and E. Breval, Mater. Res. Bull., 1993, 28, 909-914.

26 F. Sudreau, D. Petit and J. P. Boilot, J. Solid State Chem., 1989, 83, 78-90.

27 M. A. Subramanian, R. Subramanian and A. Clearfield, Solid State lonics, 1986, 18-19, 562-569.

28 J. E. Iglesias and C. Pecharromán, Solid State Ionics, 1998, 112, 309-318.

29 K. Kamali and T. R. Ravindran, J. Phys. Chem. A, 2016, 120, 1971-1977.

30 M. Barré, M. P. Crosnier-Lopez, F. Le Berre, O. Bohnké, E. Suard and J. L. Fourquet, J. Chem. Soc. Dalt. Trans., 2008, 3061-3069.

31 B. Serment, L. Corucho, A. Demourgues, G. Hadziioannou, C. Brochon, E. Cloutet and M. Gaudon, Inorg. Chem., 2019, 58, 7499-7510.

32 M. A. Tena, R. Mendoza, J. R. García and S. García-Granda, Results Phys., 2017, 7, 1095-1105.

33 A. El Jazouli, B. Tbib, A. Demourgues and M. Gaudon, Dye. Pigment., 2014, 104, 67-74.

34 M. Á. Tena, R. Mendoza, C. Trobajo, J. R. García and S. García-Granda, J. Am. Ceram. Soc., 2019, 102, 3695-3704.

35 N. Gorodylova, V. Kosinová, Ž. Dohnalová, P. Bělina and P. Šulcová, Dye. Pigment., 2013, 98, 393-404.

36 N. Gorodylova and P. Šulcová, J. Therm. Anal. Calorim., 2017, 130, 503-513.

37 N. Gorodylova, V. Kosinová, P. Šulcová, P. Bělina and M. Vlček, Dalt. Trans., 2014, 43, 15439-15449.

38 N. Gorodylova, V. Kosinová, Ž. Dohnalová, P. Šulcová and P. Bělina, J. Therm. Anal. Calorim., 2016, 126, 121-128. 